Mirjana Čižmešija*

Petar Sorić*
UDK 330.55:311.2>(497.5)

ORIGINAL SCIENTIFIC PAPER

IZVORNI ZNANSTVENI RAD

\title{
ASSESSING CROATIAN GDP COMPONENTS VIA ECONOMIC SENTIMENT INDICATOR
}

\begin{abstract}
This paper is an attempt of applying Business Survey results in creation of a holistic macroeconomic model for Croatia. Since the BUSY model (1982.), there exists an aspiration for forming a statistical business survey model that will forecast main GDP components for individual EU countries in the short run. However, the idea hasn't yet been applied in practice in Croatia. Therefore the statistical relationship between the Economic Sentiment Indicator (ESI) and corresponding official statistics series will be analyzed in order to see how the changes in ESI reflect on various segments of economic activity in Croatia. On the basis of two VAR models it can be seen that ESI can help in short-run forecasting of Croatian GDP and private consumption as its main component. It was shown that other GDP components don't exhibit a strong statistical connection with ESI.
\end{abstract}

Keywords: ESI, business survey, VAR model, GDP components

\section{INTRODUCTION}

As most economic decisions are determined by economic agents' opinions, perceptions and expectations, cyclical economic analysis witnesses a substantial growth in the importance of various Business and Consumer Surveys (BCS). The European Commission conducts business surveys in accordance with the Joint Harmonised EU Programme of Business and Consumer Surveys at the EU level (Goldrian et al., 2001). In Croatia BCS are put into practice by two different institutions. Privredni Vjesnik (Centar za poslovna istraživanja) carries out the business surveys, while the Croatian National Bank implements Consumer Surveys). BCS are quarterly surveys based on businessmen's and consumers' perceptions of their economic environment. Based on a multi-sector approach, they cover the Croatian manufacturing industry, construction, retail trade and consumer sector. For each of the mentioned sectors a Composite Confidence Indicator is formed ${ }^{1}$. Here the focus will be placed on the Economic Sentiment Indicator (ESI), which reflects and represents total economic activity. On the EU level and for all countries-participants of the Programme, ESI was designed in 1985, and has had some modifications since then (European Commission, 2007). ESI components are variables used in calculating Confidence indicators in industry, construction, retail trade, service sector and consumers, where each of them is assigned a

\footnotetext{
* Ph.D., Associate Professor, Faculty of Economics and Business, University of Zagreb, Trg J. F. Kennedyja 6 , 10000 Zagreb, Croatia, e-mail: mcizmesija@efzg.hr

* Teaching and Research Assistant, Faculty of Economics and Business, University of Zagreb, Trg J. F.

Kennedyja 6, 10000 Zagreb, Croatia, e-mail: psoric@efzg.hr

1 Industrial Confidence Indicator, Construction Confidence Indicator, Retail trade Confidence Indicator and Consumer Confidence Indicator are formed for manufacturing industry, construction, retail trade and consumer sector, respectively. An in depth analysis of BCS composite indicators on the EU level and in Croatia is presented in (Čižmešija, 2008)
} 
different weight. ${ }^{2}$ Variables and the weighting system used in the calculation of Croatia's ESI reflect structural changes in the Croatian economy. (Bahovec et al., 2007,a; Nikić et al., 2004). Business surveys in Croatia are conducted quarterly, from 1995 in manufacturing industry, construction and in retail trade. Structure of weights in the calculation of Croatian ESI indicator is determined as follows: industry $40 \%$, construction $25 \%$, retail trade $35 \%$. Consumer surveys in Croatia started later and have therefore not been included in the calculation of the ESI for the first time ${ }^{3}$.

The ESI series can be compared to the corresponding referent series published by the official National Bureau of Statistics. ${ }^{4}$ The most commonly used referent series for ESI is GDP because it reflects movements in the economy as a whole.

The aim of this paper is to analyze how accurate are Croatian economic subjects' perceptions relating to GDP and it's main components. In other words, it is essential to examine how useful is the information inherent in ESI for predicting cyclical development of private consumption (C), investments (I), government consumption $(\mathrm{G})$, exports volume (X) and imports volume (IM).

\section{LITERATURE REVIEW}

In assessing certain country's cyclical economic movements, the issue of prior interest is the construction of leading indicators that are able to offer valuable and timely information about the direction of changes in the national economy. There are a few milestone papers dealing with the issue of inspecting ESI's leading indicator properties regarding country's macroeconomic aggregates.

The first dilemma that researchers and policy holders face is whether to use measurable, real economic variables as leading indicators ${ }^{5}$ or survey-based indicators. Fritsche and Marklein (2001) observed a wide range of indicators (from real economic monetary and fiscal variables to qualitative Business and Consumer Surveys). All of them were analyzed in a vector autoregressive framework in order to question their possibility of improving short-run predictions of Euro Area industrial production. ESI turned out to have the best predictive properties (six months lead with respect to industrial production) comparing to all other indicators, including real economic variables.

Gayer (2005) considered a whole set of BCS indicators and their possible contribution to GDP forecasts of the Euro Area. Applying bivariate vector autoregressive models revealed ESI as the best leading indicator in the class of BCS indicators. Both Granger causality tests, impulse response analysis and variance decompositions corroborated such conclusions.

Silgoner (2006) analyzed a variety of BCS indicators and their predictive properties at the Euro Area level and for each country individually. Using correlation analysis, Granger causality tests and panel data models it was found that ESI offers the highest "added value" in short-run predictions of industrial production growth rate, with a lead of several months. Additionally, panel data analysis offered evidence that new EU member states have somewhat lower forecasting quality with respect to industrial production. There is a firm rationale behind such conclusions: new member states have significantly less experience in

\footnotetext{
${ }^{2}$ Structure of weights (EU level): industry 40\%, construction 5\%, retail trade 5\%, services sector $30 \%$, consumers $20 \%$.

${ }^{3}$ Surveys in the services sector started in the 3 rd quarter of 2008

${ }^{4}$ At the EU level ESI series is compared to referent series published by Eurostat.

5 There is a whole variety of literature on constructing composite indicators on the basis of real economic data. See e.g. (OECD, 2008), or (Ahec-Šonje, 2000) for two different approaches.
} 
implementing Business and Consumer Surveys. Both institutions that carry out the surveys and the respondents need experience to properly assess the economy's cyclical movements.

\section{METHODOLOGICAL GROUND}

The ESI quarterly series $(1997 / \mathrm{I}=100)$ is compared with the corresponding series of GDP indices (1997/I=100), and GDP components, as published by the Croatian Bureau of Statistics. The dataset refers to the time period 1997Q1-2008Q1. All used series are seasonally adjusted ${ }^{6}$ and expressed in natural logarithms.

Earlier studies and analysis of business cycles using BCS data in Croatia were based on fundamental statistical methods such as correlation analysis or the analysis of coincidence in the direction of change of leading indicators and referent macroeconomic series (Čižmešija, 2001). In addition, in more recent studies the Granger causality tests were also applied (Lang, 2001; Bahovec et al., 2007,b). The essential and the most important reason for implementing the mentioned techniques is the fact that Business surveys have been launched in 1995 in Croatia, so until now the observed time series haven't had enough observations to apply more advanced and robust techniques such as VAR analysis. From today's perspective, a respectable dataset has been formed, which enables the application of VAR modeling done here.

In order to analyze the interrelations between the observed variables, two vector autoregressive models (VAR) were formed. Generally, such models can be presented in the following way:

$$
y_{t}=A_{0}+A_{1} y_{t-1}+\ldots+A_{p} y_{t-p}+u_{t}
$$

where $y_{t}$ is a $k \times 1$ random vector, $A_{0}$ is a $k \times 1$ vector of intercept terms, the $\mathrm{A}_{i}$ are $k \times k$ matrices of coefficients and $u_{t}$ is a $k \times 1$ vector of error terms, $k$ being the number of observed variables $^{7}$ (Asteriou, 2006).

\section{Empirical results}

The first VAR model captured the relationship between ESI and GDP, while the other one enabled the exploration of ESI's predictive properties regarding GDP's components ${ }^{8}$.

First of all, variables of interest were formally tested for unit root presence using the Augmented Dickey-Fuller (ADF) test. The results given in the following table unambiguously suggest that all variables exhibit mean-reverting properties after differencing. Therefore all series can be treated as $I(1)$, i.e. integrated of order one.

\footnotetext{
${ }^{6}$ DAINTIES seasonal adjustment method is applied.

${ }^{7} \mathrm{k}$ equals 2 in the first VAR, and 6 in the second one.

${ }^{8}$ Considering that GDP is composed of all other observed real economic variables, this dichotomic approach was applied in order to avoid multicolinearity problems.
} 
Table 1:

ADF unit root test for all observed series in level

\begin{tabular}{|l|l|l|l|}
\hline Variable & $\begin{array}{l}\text { ADF value } \\
\text { trend and constant included }\end{array}$ & $\begin{array}{l}\text { ADF value } \\
\text { Constant } \\
\text { included }\end{array}$ & ADF value \\
\hline$G D P$ & $-2.125436(0)$ & $0.313437(0)$ & $4.056350(0)$ \\
\hline$C$ & $-1.994790(0)$ & $1.162818(2)$ & $2.952208(2)$ \\
\hline$I$ & $-1.665788(0)$ & $0.613548(0)$ & $3.087548(0)$ \\
\hline$G$ & $-2.931466(1)$ & $-2.464232(1)$ & $0.634071(1)$ \\
\hline$X$ & $-2.157752(1)$ & $0.418953(1)$ & $2.676092(1)$ \\
\hline$I M$ & $-2.177024(0)$ & $1.142019(1)$ & $3.413062(1)$ \\
\hline$E S I$ & $-2.893707(0)$ & $-1.251110(0)$ & $0.495043(0)$ \\
\hline
\end{tabular}

Notes: Optimal lag number is given in brackets.

Table 2:

ADF unit root test for all observed series in first differences

\begin{tabular}{|l|l|l|l|}
\hline Variable & $\begin{array}{l}\text { ADF value } \\
\text { trend and constant } \\
\text { included }\end{array}$ & $\begin{array}{l}\text { ADF value } \\
\text { Constant } \\
\text { included }\end{array}$ & ADF value \\
\hline$\Delta \mathrm{GDP}$ & $-7.698766^{* *}(0)$ & $-7.684656^{* *(0)}$ & $-5.594424^{* *(0)}$ \\
\hline$\Delta \mathrm{C}$ & $-6.181264^{* *}(1)$ & $-5.713618^{* *(1)}$ & $-5.669688^{* *}(0)$ \\
\hline$\Delta \mathrm{I}$ & $-5.791028^{* *}(0)$ & $-5.729571^{* *(0)}$ & $-4.795939 * *(0)$ \\
\hline$\Delta \mathrm{G}$ & $4.101476^{*}(0)$ & $-4.163127^{* *(0)}$ & $-4.145272^{* *(0)}$ \\
\hline$\Delta \mathrm{X}$ & $-6.874538^{* *}(0)$ & $-6.768126^{* *(0)}$ & $-2.844850^{* *(2)}$ \\
\hline$\Delta \mathrm{IM}$ & $-7.645071^{* *}(0)$ & $-7.217000^{* *(0)}$ & $-2.361790^{*}(2)$ \\
\hline$\Delta \mathrm{ESI}$ & $-7.833185^{* *}(0)$ & $-7.830337^{* *}(0)$ & $-7.853829 * *(0)$ \\
\hline
\end{tabular}

Notes: $\Delta$ is the first difference operator. One (two) asterisk(s) denotes rejection of the null hypothesis at $5 \%(1 \%)$ significance level. Optimal lag number is given in brackets.

Hence all following VAR modeling will be conducted using variables in first differences. At this point the analysis is carried out for the bivariate VAR model. The optimal lag number in the first VAR was set at 2 using AIC information criterion.

From the aspect of economic policy holders in Croatia, the time of precedence (in months or quarters) of ESI to GDP would represent extremely useful information. Therefore the issue of highest relevance here is to examine the possibility of using ESI as a short-run predictor of 
main macroeconomic variables. At this step the Granger causality test was conducted. It questions whether current and past values of ESI help to forecast future values of GDP (Enders, 2004.).

Table 3:

\section{Granger causality test for ESI and GDP}

\begin{tabular}{|l|l|l|}
\hline Null hypothesis: & F-statistic & $\mathrm{p}$-value \\
\hline$\Delta$ ESI does not Granger cause $\Delta$ BDP & $\mathbf{3 . 0 6 2 6 0}$ & $\mathbf{0 . 0 5 8 7 8}$ \\
\hline$\Delta$ BDP does not Granger cause $\Delta$ ESI & 1.89782 & 0.16420 \\
\hline
\end{tabular}

According to the obtained test statistics, it seems that ESI can be used by economic researchers and policy holders as a short-term indicator of future Croatian economic movements ${ }^{9}$. In other words, ESI Granger causes GDP because the shifts in the sentiment indicator precede to those of GDP. The causality, however, isn't valid in both directions.

The dynamics of the observed relationship could be more perceptible using impulse response analysis.

\section{Figure 1:}

Impulse response of $\Delta$ GDP to $\Delta \mathrm{ESI}$

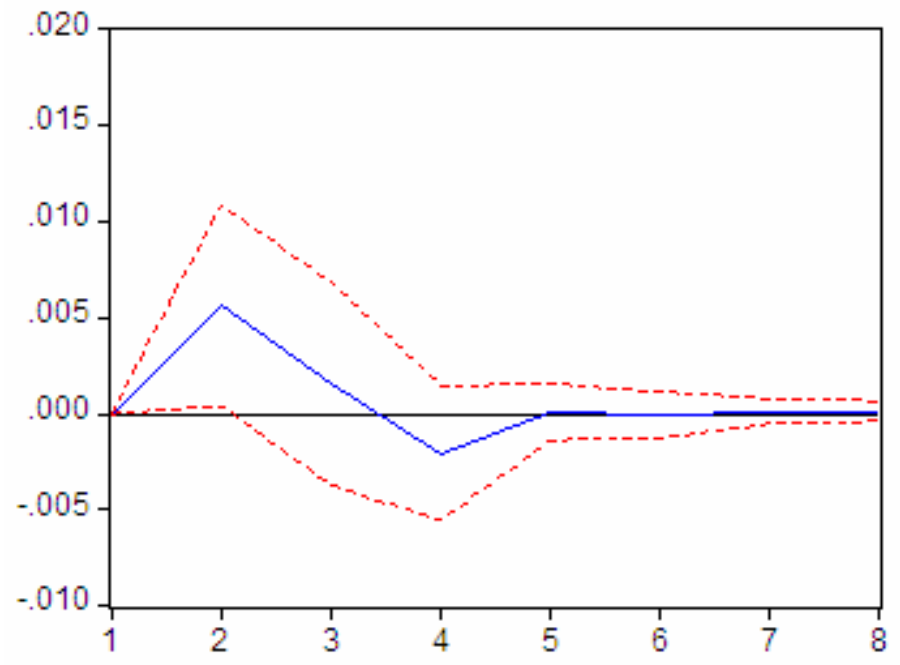

As a result of a one standard deviation rise in the variable $\Delta \mathrm{ESI}, \Delta \mathrm{GDP}$ reacts after one quarter, and with a $0.5 \%$ improvement. Afterwards the shock in ESI fades away and GDP stabilizes.

The so far conducted analysis will be corroborated with the variance decomposition.

Table 4:

Variance decomposition of GDP
\begin{tabular}{|l|l|l|}
\hline Period & $\Delta$ GDP & ESI \\
\hline 1 & 100.0000 & 0.000000 \\
\hline 2 & 89.37147 & 10.62853 \\
\hline 4 & 87.44268 & 12.55732 \\
\hline 6 & 87.46499 & 12.53501 \\
\hline 8 & 87.45828 & 12.54172 \\
\hline
\end{tabular}

The results show that the variable $\Delta$ GDP itself explains $100 \%$ of it's forecasting error variance in the first future period. Here $\Delta$ ESI becomes relevant with two quarters ahead when

\footnotetext{
${ }^{9}$ At $10 \%$ significance level
} 
$10.63 \%$ of the error in the forecast of $\Delta \mathrm{GDP}$ is attributed to it. Afterwards ESI's influence stabilizes at around rather high $12.5 \%$.

In the second VAR model 4 lags were used, as suggested by the AIC criterion.

Table 5:

Granger causality test for ESI and GDP components

\begin{tabular}{|l|l|l|}
\hline Null hypothesis: & F-statistic & $p$-value \\
\hline$\Delta$ ESI does not Granger cause $\Delta \mathrm{C}$ & $\mathbf{5 . 6 6 5 7 9}$ & $\mathbf{0 . 0 0 1 5 3}$ \\
\hline$\Delta$ C does not Granger cause $\Delta \mathrm{ESI}$ & $\mathbf{3 . 1 9 1 9 3}$ & $\mathbf{0 . 0 2 6 3 2}$ \\
\hline$\Delta$ ESI does not Granger cause $\Delta \mathrm{I}$ & 0.74884 & 0.56632 \\
\hline$\Delta$ I does not Granger cause $\Delta \mathrm{ESI}$ & 1.83965 & 0.14635 \\
\hline$\Delta$ ESI does not Granger cause $\Delta \mathrm{G}$ & 0.72973 & 0.57854 \\
\hline$\Delta$ G does not Granger cause $\Delta \mathrm{ESI}$ & 1.11568 & 0.36690 \\
\hline$\Delta$ ESI does not Granger cause $\Delta \mathrm{X}$ & 0.89695 & 0.47761 \\
\hline$\Delta$ X does not Granger cause $\Delta \mathrm{ESI}$ & $\mathbf{3 . 1 9 7 4 2}$ & $\mathbf{0 . 0 2 6 1 4}$ \\
\hline$\Delta$ ESI does not Granger cause $\Delta \mathrm{IM}$ & 0.64384 & 0.63535 \\
\hline$\Delta$ IM does not Granger cause $\Delta \mathrm{ESI}$ & $\mathbf{2 . 7 6 8 7 1}$ & $\mathbf{0 . 0 4 4 6 3}$ \\
\hline
\end{tabular}

Here it is clearly visible that there exists Granger causality in both directions between $\Delta$ ESI and $\Delta \mathrm{C}$. Such results are actually quite expected and can easily be economically interpreted. Namely, throughout the whole observed period private consumption has been a major part of Croatian GDP, with mild fluctuations around a $60 \%$ share level (www.dzs.hr, author's calculation) ${ }^{10}$. Therefore the obtained results point out that Croatian private sector reacts to the improvement of business climate by directing it's capital excess in consumption. It should also be remarked that changes in Croatian foreign trade results (either the exports or imports) reflect on economic subject's perceptions of the total business climate. Considering the fact that Croatia is a small open economy, it is fairly logical that, from the aspect of economic agents, alternations of foreign goods and services accessibility and the Croatian exports variations signify shifts in Croatian economy per se.

Table 6:

\section{Variance decomposition for private consumption}

\begin{tabular}{|l|l|l|l|l|l|l|}
\hline Period & $\Delta \mathrm{C}$ & $\Delta \mathrm{I}$ & $\Delta \mathrm{G}$ & $\Delta \mathrm{X}$ & $\Delta \mathrm{IM}$ & $\Delta$ ESI \\
\hline \multirow{3}{*}{$\begin{array}{l}2 \\
4\end{array}$} & 100,00 & 0,00 & 0,00 & 0,00 & 0,00 & 0,00 \\
\cline { 2 - 7 } & 36,97 & 0,96 & 54,57 & 1,24 & 0,45 & 5,81 \\
\cline { 2 - 7 } & 28,50 & 17,59 & 35,95 & 2,19 & 10,82 & 4,95 \\
\cline { 2 - 7 } 8 & 29,31 & 14,69 & 35,50 & 3,37 & 9,05 & 8,08 \\
\cline { 2 - 7 } & 28,36 & 15,11 & 33,88 & 4,16 & 9,64 & 8,85 \\
\hline
\end{tabular}

It is easily observable from Table 4 that ESI exhibits a moderate, but still existing influence on the private consumption in Croatia (the share of forecast error variance explained by ESI is $5,81 \%$ after two quarters, rising up to $8,85 \%$ after two years). ${ }^{11}$

\footnotetext{
10 For a more thorough analysis of personal consumption's role in generating Croatian GDP, see e.g. (Lovrinčević and Mikulić, 2003)

11 According to this analytical tool, ESI turned out to have unsatisfactory prognostic properties (which was previously indicated by the Granger causality test). The remaining variance decomposition results are not shown in order to save space but can be obtained by the authors upon request.
} 
The remaining figure captures the influence of a one standard deviation shock in ESI on all observed GDP components.

\section{Figure 2:}

a) 1

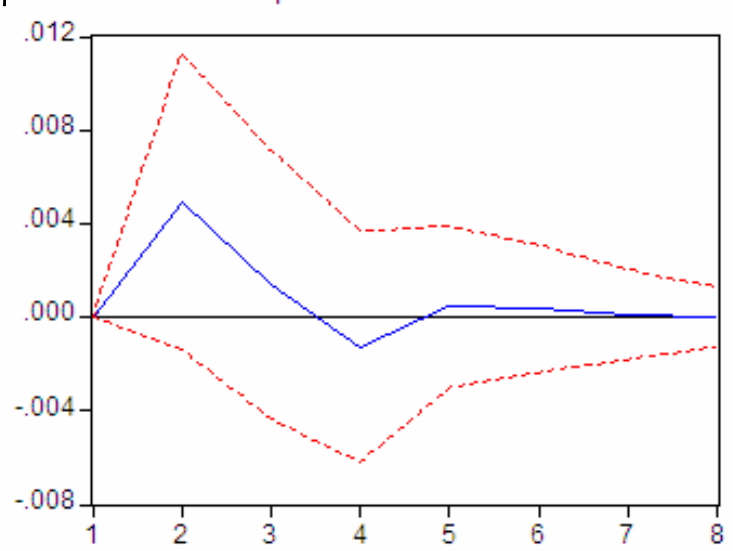

c)

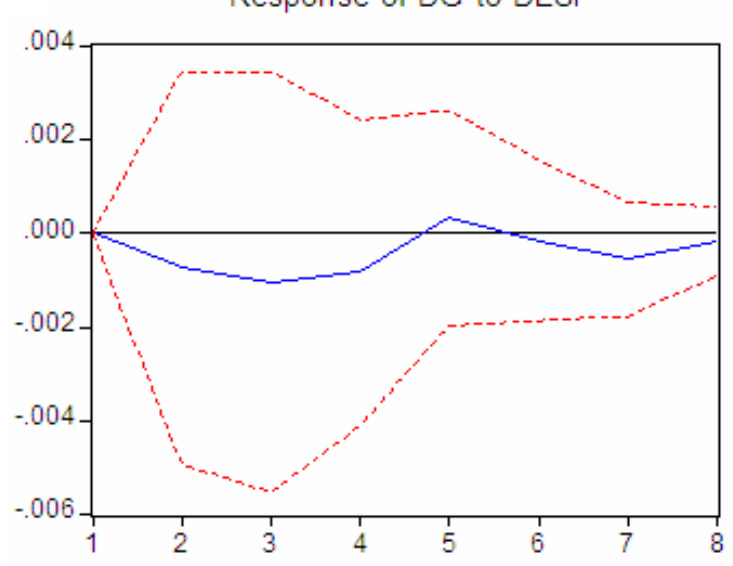

b)

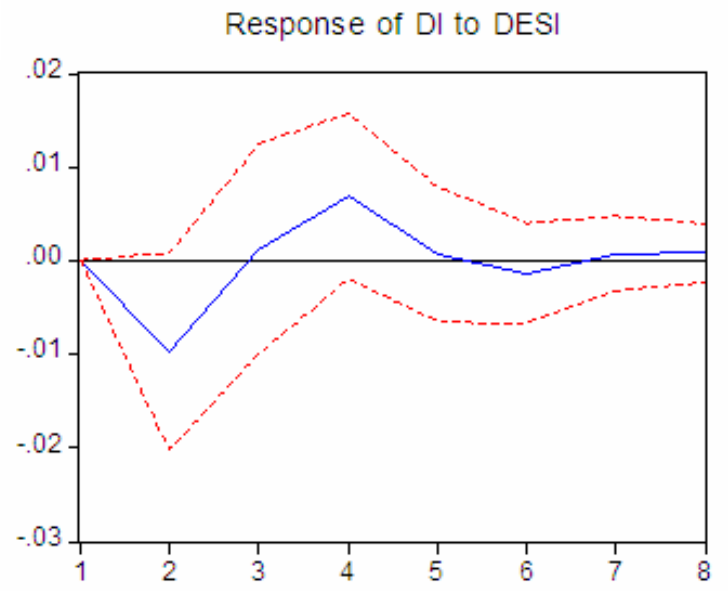

d)

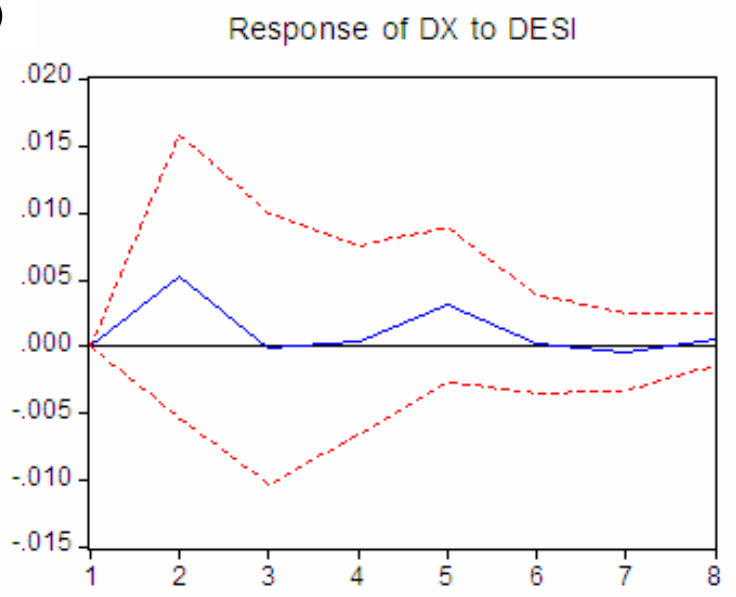

e) Response of DIM to DESI

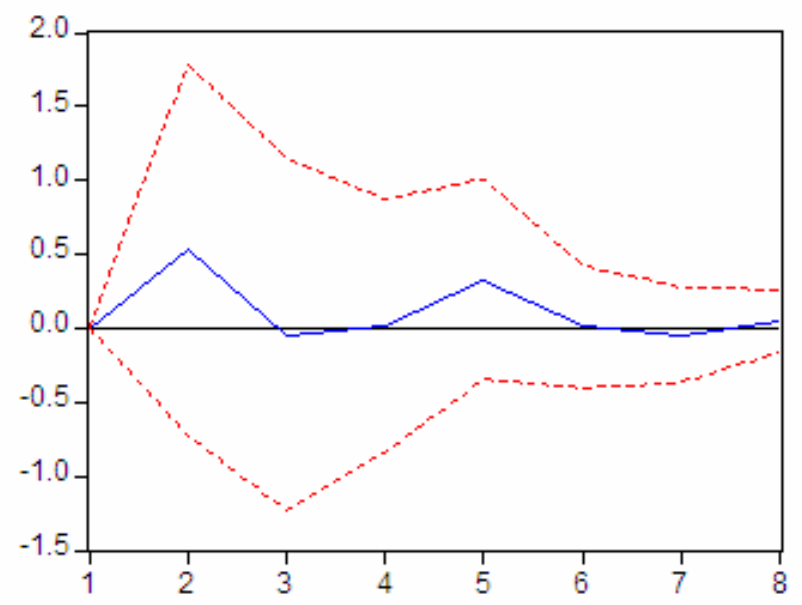


From the first two parts of the figure a certain pattern can easily be observed. Namely, an initial response to a shock in ESI is a rise of private consumption and a downfall of investments, which indicates the existence of the so-called crowding-out effect. Such interrelations can dominantly be addressed to the structure of Croatian GDP (i.e. prevailing of private consumption component in Croatian GDP). Another factor that easily might influence such results is the ESI weighting system in Croatia. Namely, retail trade accounts for a respectable $35 \%$ weight in ESI calculation ${ }^{12}$. Construction sector, on the other hand accounts for a smaller, $25 \%$ weight. Inspecting a) and b) graphs more carefully discovers that the mentioned opposite movements of $C$ and $I$ coincide in every future period, revealing the presence of cyclical behavior in Croatian economy. Such cyclical properties are also observed for all other GDP components of interest here. It is also worth mentioning here that, due to the imports dependence of Croatian economy, imports react most intensively on ESI movements. Such unsatisfactory ESI's leading indicators properties vis-à-vis smaller GDP components can partly be attributed to a rather short period of implementing the BCS (less experience of institutions and respondents) in comparison to most EU members.

\section{CONCLUDING REMARKS}

This paper investigated the possibility of using ESI indicator as a short-term predictor of Croatian GDP and it's main components. Through a bivariate VAR it was shown that GDP movements can more aqurately be described using ESI series. The second model resulted in somewhat different results. Namely, it was shown that ESI Granger causes only Croatian private consumption, while other GDP components haven't revealed a significant statistical relationship. To sumarize, according to the models proposed in this paper it is obvious that ESI can be used both to identify the tipping points of Croatian economy as a whole and those of private consumption as the largest Croatian macroeconomic aggregate. Other components, however, can not be statistically explained by ESI movements. Policy implications of these results are fairly straightforward. ESI represents a timely and efficient signal for economic policy holders in anticipating recessional movements of the national economy as a whole and of personal consumption as the main component of Croatian GDP. That way it is possible to undertake appropriate countercyclical measures even before the actual economic downfall. Therefore this confirms the necessity of supplementing conventional macroeconomic forecasting tools with Business Surveys. Nevertheless, in assessing other GDP components, specificities of individual sectors should be taken into account instead of applying a wide composite indicator such as ESI.

Moreover, the benefit of this research is not only for professional economists and policy holders, but for all non-economists faced with every day decisions about consumption, investments of any type, savings etc. Timely information about e.g. recession development would significantly improve the quality of their economic decisions.

\footnotetext{
${ }^{12}$ For a more detailed discussion on the interdependence between the consumers and retail trade sector, see e.g. (Dudek, 2008) and (Nahuis and Jos Jansen, 2004)
} 


\section{REFERENCES}

1. Ahec-Šonje, A. (2000) Ekonomska prognostika u Hrvatskoj: CROLEI indeks, Privredna kretanja i ekonomska politika, No.80, pp. 43-74

2. Asteriou, D. (2006.), Applied econometrics, Palgrave Macmillan

3. Bahovec, V. Čižmešija. M., Kurnoga - Živadinović, N. (2007.) Croatian Economic Sentiment Indicator: New Components and a New Weighting System. The 56th Session of the international statistical Institute, Lisboa, Portugal, 22-29 August 2007.

4. Bahovec, V., Čižmešija, M., Kurnoga Živadinović, N. (2007) Testing for Granger causality between economic sentiment indicator and gross domestic product for Croatian economy, 9th International Symposium on Operational Research (SOR 07), Nova Gorica, Slovenija, rujan 2007.

5. Čižmešija, M. (2001) Statističko-metodološka podloga konjunkturnih testova, doktorska disertacija, Ekonomski fakultet, Sveučilište u Zagrebu

6. Čižmešija,M (2008) Konjunkturni testovi Europske unije i Hrvatske, Privredni vjesnik, Zagreb

7. Dudek, S. (2008) Consumer Survey Data and short-term forecasting of households consumption expenditures in Poland, $29^{\text {th }}$ CIRET conference, Santiago, October 2008

8. Enders, W (2004.) Applied Econometric Time Series, $2^{\text {nd }}$ edition, Wiley

9. European Commission (2007.) European Economy, The Joint Harmonised EU Programme of Business and Consumer Surveys, User Guide updated 04/07/2007. Brussels.

10. Fritsche, U. and Marklein, F. (2001) Leading Indicators of Euroland Business Cycles, DIW Discussion Paper No.238, Berlin

11. Gayer, C. (2005) Forecast Evaluation of European Commission Survey Indicators, Journal of Business Cycle Measurement and Analysis, 2, str.157-183

12. Goldrian,G., Lindlbauer,D., Nerb,G. (2001). Evaluation and development of confidence indicators based on harmonised business and consumer surveys, Study of the IFO Institue for Economic Research.

13. Lovrinčević.Ž. and Mikulić,D (2003) Personal Consumption Modeling in the Republic of Croatia by using the Error Correction Model, Ekonomski pregled 54 (9-10) 725-759

14. Nahuis, N.J. and Jos Jansen W. (2004) Which Survey Indicators Are Useful for Monitoring Consumption? Evidence from European Countries, Journal of Forecasting, No.23, pp.89-98. 
15. Nikić, G. Šošić, I. Čižmešija, M. (2004). Estimate of ESI in Croatia - a case study of an economy in transition, 27th CIRET Conference, Warsaw, September 2004.

16. OECD,(2008) Handbook on constructing composite indicators: Methodology and user guide (2008) European commission, Joint Research centre, available at

www.oecdbookshop.org/oecd/display.asp?lang=en\&sf1=DI\&st1=5KZN79PVDJ5J [8.12.2008.]

17. Silgoner, M.A. (2006) An Overview of European Economic Indicators, $28^{\text {th }}$ CIRET Conference, Rome, September 2006

18. http://www.ciret.org/

19. www.dzs.hr

\title{
PROCJENA KOMPONENTI HRVATSKOG BDP-A UZ POMOĆ POKAZATELJA EKONOMSKOG RASPOLOŽENJA
}

\begin{abstract}
Sažetak
Ovaj rad je pokušaj primjene rezultata konjunkturnih istraživanja u kreiranju holističkog makroekonomskog modela za hrvatsko gospodarstvo. Intencija formiranja kratkoročnog prognostičkog modela osnovnih komponenata BDP-a korištenjem konjunkturnih indikatora postoji u zemljama članicama EU još od BUSY modela (1982.). Takva ideja, međutim, dosad nije u praksi primijenjena u Hrvatskoj. Stoga će ovdje biti analiziran statistički odnos između Pokazatelja ekonomskog raspoloženja (ESI) $i$ odgovarajućih nizova službene statistike, $i$ to s ciljem analize utjecaja promjena ESI indikatora na pojedinačne gospodarske sektore u RH. Na osnovi dva VAR modela zaključuje se da se ESI može koristiti u kratkoročnom prognoziranju hrvatskog BDP-a, $i$ privatne potrošnje kao njegove osnovne komponente. Također se pokazalo da ESI ne karakterizira snažna veza s ostalim komponentama BDP-a.
\end{abstract}

Ključne riječi: ESI, konjunkturna istraživanja, VAR model, komponente BDP-a 